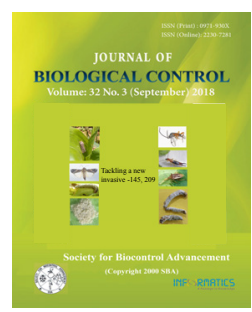

\title{
Natural occurrence of predatory bugs, Eocanthecona furcellata (Wolff) and Andrallus spinidens (Fabr.) on Spodoptera frugiperda (Smith) (Hemiptera:Pentatomidae) in maize and their potential in management of fall army worm
}

\author{
A. N. SHYLESHA ${ }^{1}$ and ACHANTA SRAVIKA ${ }^{2 *}$ \\ ${ }^{1}$ Division of Germplasm Conservation and Utilisation, ICAR-NBAIR, Hebbal, Bengaluru - 560024, Karnataka, India \\ ${ }^{2}$ Department of Entomology, UAS Bengaluru - 560065, Karnataka, India \\ *Corresponding authorE-mail: anshylesha@gmail.com
}

\begin{abstract}
Two species of predacious bugs, Eocanthecona furcellata (Wolff) and Andrallus spinidens (Fabr.) (Hemiptera:Pentatomidae) were found effectively preying on Spodoptera frugiperda (Smith) in organically grown maize from 28 to 56 days at GKVK, Bangalore. Population of E. furcellata in one square metre was more than A. spinidens during the $38^{\text {th }}$ and $39^{\text {th }}$ standard meteorological weeks. Adults and nymphs of both the species preyed on different stages of $S$. frugiperda larvae. These two species being initial colonizers has a potential in integrated management of fall army worm.
\end{abstract}

KEY WORDS: Andrallus spinidens, Eocanthecona furcellata, Spodoptera frugiperda

(Article chronicle: Received: 02-08-2018; Revised: 15-09-2018; Accepted: 25-09-2018)

The invasive fall army worm, Spodoptera frugiperda (Smith) was reported in India recently and is spreading fast in the subcontinent. Several local natural enemies are colonizing on the new species either by feeding directly or by parasitizing the same. Some of the common predatory insects were also found feeding like the predatory earwigs, ladybird beetles, Assassin bugs, big eyed bugs (Geocoridae), and wasps. Pathogens like Nomuraea rileyi and Nuclear Polyhedrosis Viruses (NPV) were also recorded from India.

Two species of predacious bugs Eocanthecona furcellata (Wolff) and Andrallus spinidens (Fabr.) (Hemiptera:Pentatomidae) that are efficient lepidopteran caterpillar predators in orchards, soyabean, beans, vegetable and forest ecosystems (Navarajanpaul, 2002) were found feeding on fall army worm, $S$. frugiperda in maize.

The pentatomid bug, Eocanthecona furcellata (Wolff) is an effective generalist predator of Lepidoptera, Coleoptera, and Heteroptera widely distributed in the oriental region, particularly South-east Asian countries including India, China, Indonesia, Taiwan and Japan and the predator has often been observed in cotton, chickpea, groundnut and vegetable crops (Clercq, 2000). It has been identified as an effective biological control agent against various lepidopteran pests. In India E. furcellata had been an important predator on several important caterpillar pests, such as larvae of Earias sp. (Pant, 1960), Spodoptera litura (F.) on daincha (Cherian and Brahmachari, 1941), Eutectona machaeralis (Walker), Hyblaea puera (Cramer), Plecoptera reflexa (G.), S. litura (F.) (Ahmad et al., 1996), rice leaf folder, Cnaphalocrocis medinalis Guenee (Kumar and Singh, 2007), Helicoverpa armigera Hubner, Spilarctia obliqua (W.) and Trichoplusia $n i$ (Hubner) on sunflower (Basappa, 2011) and Maruca vitrata Geyer on pigeonpea (Nebapure and Agnihotri, 2011).

Andrallus spinidens is another pentatomid predator, which is widely distributed in tropical and warm temperate zones worldwide. Adults are sombre brown. Scutellum dark brown, apically yellowish with hemelytra dark brown, with sub marginal yellowish stripes running along entire length and often males with a pair of glandular pubescent patches on ventral side of abdomen. It inhabits grasslands, rice fields, and several other crops and kills many kinds of lepidopteran, coleopteran, and hymenopteran larvae (Shintani et al., 2010). It is also recorded as a predator of Spodoptera litura, S. mauritia, Melanitis leda ismene, Naranga aenescens, and Helicoverpa armigera. It has been reported to feed on the mexican beetle, Zygogramma bicolorata (Pandey et al., 2002), commonly found on crops like rice (Manley, 1982; Pawar, 1976) and cotton. 
Andrallus spinidens is a cosmopolitan species widely distributed in the Oriental (China, Taiwan, Philippines, Japan, Malaysia, Indonesia, Vietnam, Bangladesh), Australasian (Australia, New Guinea) and Afro tropical regions; parts of Europe and North America and in India reported from the states of Jammu \& Kashmir; Karnataka; Uttaranchal; West Bengal.

Weekly observations were taken to know the incidence of pentatomid predator's from organically grown maize fields at GKVK, Bangalore. A population in one square meter area was recorded by following the visual counting method (no./plant).

In present survey peak population of Eocanthecona furcellata (Figure 1) was observed during the $38^{\text {th }}$ and $39^{\text {th }}$ standard meteorological week which coincided with 28 to 56 days of maize growth wherein the population of fall army worm was severe. The field was highly infested with at least two caterpillars per plant. Fall army worm incidence started at 15-16 day old crop and coincided with $34^{\text {th }}$ standard week. Good larval population along with the predatory pentatomdids appeared during the $35^{\text {th }}$ week and continued up to $42^{\text {nd }}$ week. A mean E. furcellata population of 4 , per square metre in $38^{\text {th }}, 6$ during $39^{\text {th }}$ and 3 during $40^{\text {th }}$ standard week was observed and the population was negligible in later observations as there was no fall army worm larval population in field. One egg mass during the $38^{\text {th }}$ week and 3 egg mass during the $39^{\text {th }}$ week and $40^{\text {th }}$ week were observed. Similar observations was recorded previously on other host caterpillars by Snehel et al. (2017) who reported that the predator marked its first appearance during $36^{\text {th }}$ meteorological standard week at flowering and pod initiation stage of pigeon pea, with scanty population of 1.2 bugs/ sq. $\mathrm{m}$ and 1.6 bugs $/ \mathrm{M}^{2}$ respectively, followed by a gradual increase and attained peak population of $5.8 \mathrm{bugs} / \mathrm{M}^{2}$ and 6.4 bugs $/ \mathrm{M}^{2}$ respectively during $39^{\text {th }}$ standard week predating on S. litura, Grapholita critica and M. vitrata, after which the population declined markedly in the following weeks ( $43^{\text {rd }}$ to $47^{\text {th }}$ standard week) and attained lowest population ( $0.6 \mathrm{bugs} /$ $\mathrm{M}^{2}$ and 0.4 bugs $/ \mathrm{M}^{2}$ respectively) during $47^{\text {th }}$ meteorological standard week.

The population of Andrallus spinidens was very less and only 2 adults were found feeding on S. frugiperda (Figure 2.) during the $38^{\text {th }}$ and $39^{\text {th }}$ standard weeks. However the adults and nymphs were found actively feeding on different stages of the fall army worm in the field.

Eocanthecona furcellata and Andrallus spinidens are amenable for mass rearing in the laboratory on different hosts like S. frugiperda, S. litura, Samia cynthia and Corcyra cephalonica. These predators can be effectively used in managing the $S$. frugiperda pest outbreak by augumentation.
The maximum per cent predation of $M$. vitrata by this bug was 56 per cent under laboratory conditions (Pillai and Agnihotri, 2013). A. Spinidens reared on S. litura feed on and kill as many as 100 larvae during their adult life (Shintani et al., 2010).

Both the predators are amenable for mass production using laboratory hosts like Galleria or Spodoptera litura throughout the year and are easy to maintain and release. The insects can be spread in the field at second or third nymph stage so that they target the pests and manage them effectively. This will be very much suited for pest management in organic maize production.

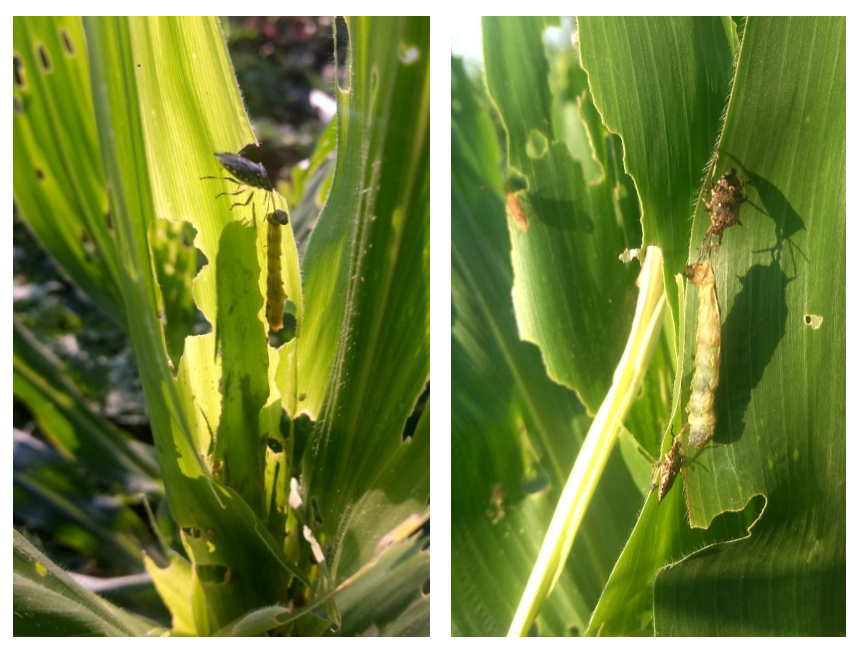

Fig. 1. Eocanthecona furcellata feeding on Spodoptera frugiperda.

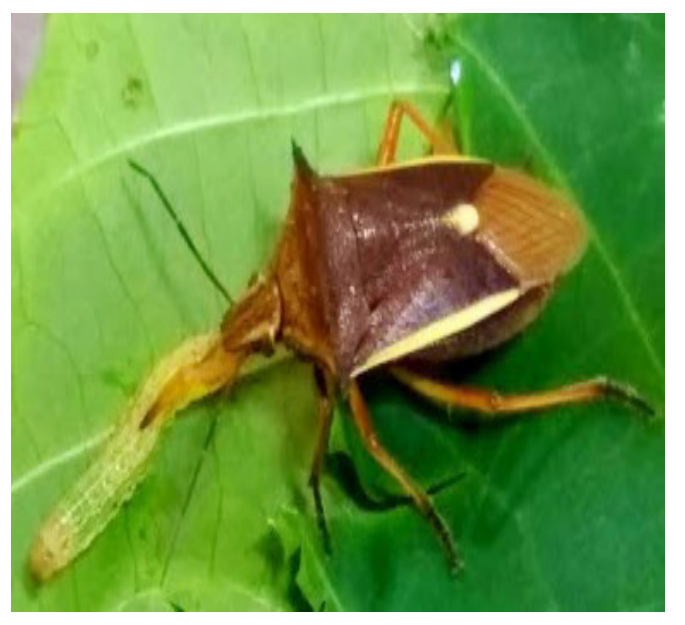

Fig. 2. Andrallus spinidens feeding on Spodoptera frugiperda.

\section{REFERENCES}

Clercq PD. 2000. Predaceous stink bugs (Pentatomidae: Asopinae): Heteroptera of economic importance. CRC press, Boca Raton, pp. 737-789. https://doi. org/10.1201/9781420041859.ch32 
Manley GV. 1982. Biology and life history of the rice field predator Andrallus spinidens F. (Hemiptera: Pentatomidae). Entomological News 93: 19-24.

Navarajanpaul AV. 2002. Biological control of lepidopteran pests using important predators, Proceedings of the symposium on biological control of lepidopteran pests, Bangalore, pp. 19-28.

Pandey SP, Joshi BD, Tiwari LD. 2002. First report of a new predator, Andrallus spinidens (Fabr.), on mexican bettle, Zygogramma bicolorata (Pallister) from Uttaranchal, India. Indian J Entomol. 64(1): 113-116.

Pawar AD. 1976. Andrallus spinidens (Fabricius) (Asopinae: Pentatomidae: Hemiptera) as a predator of insect pests of rice in Himachal Pradesh, India. Rice Entomologists Newslett. 4: 23-24.
Shintani Y, Masuzawa Y, Hirose Y, Miyahara R, Watanabe F, Tajima J. 2010. Seasonal occurrence and diapause induction of a predatory bug Andrallus spinidens (f.) (heteroptera: pentatomidae). Entomol Sci. 13: 273-279. https://doi.org/10.1111/j.1479-8298.2010.00386.x

Singh RN, Saratchandra, Beera. 2002. Biological control of the pentatomid stink bug, Eocanthecon furcellata (Wolff.), by using their parasitoid, Psix straiticeps Dodd, in sericulture. Int J Indust Entomol. 5(1): 13-22.

Snehel C, Meena A, Jagdish J. 2017. Seasonal abundance of predatory bugs, Eocanthecona furcellata (Wolff.) and Rhynocoris fuscipes (F.) and its olfactory responses towards plant and pest mediated semiochemical cues in Pigeonpea ecosystem. Legume Res. 40(2): 351-357. 